\title{
Aktivitas Antibakteri Minyak Sirih Merah (Piper Crocatum Ruiz \& Pav.) Dalam Bentuk Sediaan Emulsi dan Mikroemulsi
}

\author{
Antibacterial Activities of Red Flow Oil (Piper Crocatum Ruiz \& Pav.) in The \\ Form of Emulsion and Microemulsi
}

Elsa Putri Kartika, Marchaban*, Sudarsono

Fakultas Farmasi, Universitas Gadjah Mada

Corresponding author: Marchaban: Email: marchaban@yahoo.com

\begin{abstract}
ABSTRAK
Minyak Sirih Merah (MSM) diketahui mempunyai aktivitas sebagai antibakteri dan dapat dibuat dengan cara distilasi air dan uap dari daun sirih merah (Piper crocatum Ruiz \& Pav.). Tujuan dari studi ini adalah untuk membandingkan aktivitas antibakteri dari MSM apabila diformulasi dalam bentuk sediaan yang berbeda (yaitu emulsi dan mikroemulsi). MSM dalam bentuk emulsi dibuat dengan cara mencampur 0,125 g MSM, 0,875 g paraffin cair, 0,125 g tween-80, 0,375 g span-80 (HLB 7), dan 3,500 g air. MSM dalam bentuk mikroemulsi dibuat dengan mencampur 0,125 g MSM, 0,125 g paraffin cair, 0,625 g tween80, 0,625 g PEG-400, dan 3,500 g air. Aktivitas antibakteri terhadap Escherichia coli ATCC 25922 dilakukan dengan menggunakan metoda mikrodilusi dengan 1\% w/w konsentrasi menggunakan reader ELISA pada $570 \mathrm{~nm}$. Data kemudian dianalisis untuk membandingkan persentase penghambatan pertumbuhan mikroba. Hasil penelitian menunjukkan bahwa hambatan bakteri dari MSM dalam bentuk emulsi adalah 17,45 $\pm 5,9 \%$ sedangkan dalam bentuk mikroemulsi 49,58 $\pm 3,27 \%$. Kesimpulannya adalah aktivitas antibakteri MSM dalam bentuk mikroemulsi lebih baik dari bentuk emulsi.
\end{abstract}

Kata kunci : daun sirih merah, emulsi, mikroemulsi, antibakteri

\begin{abstract}
The red sirih essential oil (RSEO) known has antibacterial activity and can be obtained by water and steam distillation of red betel leaf (Piper crocatum Ruiz \& Pav.). The aim of this study is to compare its bacterial activity if the RSEO is formulated in different dosage forms (i.e. emulsion and microemulsion). The RSEO in emulsion dosage form was prepared by stirring $0.875 \mathrm{~g}$ of liquid paraffin, $0.125 \mathrm{~g}$ RSE0, $0.125 \mathrm{~g}$ of tween-80, $0.375 \mathrm{~g}$ of span-80 (HLB 7), and $3.500 \mathrm{~g}$ of water. The RSEO in microemulsion dosage form was prepared by stirring $0.125 \mathrm{~g}$ of liquid paraffin, $0.125 \mathrm{~g}$ RSEO, $0.417 \mathrm{~g}$ Tween $80,0.833 \mathrm{~g}$ of PEG-400 and $3.500 \mathrm{~g}$ of water. Antibacterial activity against Escherichia coli ATCC 25922 was done by using microdilution method at $1 \%$ of w/w concentration using the ELISA reader at $570 \mathrm{~nm}$. The data was then to be analysed to compare the percentage of inhibition of the bacterial growth. The results showed that the bacterial inhibition of RSEO in emulsion dosage form was $17.45 \pm 5.9 \%$ while in microemulsion dosage form was $49.58 \pm 3.27 \%$. It is concluded that the RSEO had a better antibacterial activity in the forms of microemulsion than emulsion.
\end{abstract}

Keyword: Red betel leaf, emulsion, microemulsion, antibacterial 


\section{PENDAHULUAN}

Indonesia termasuk negara dengan berbagai tanaman yang mengandung metabolit primer dan metabolit sekunder, yang dipercaya mempunyai khasiat sebagai obat. Tanaman yang berfungsi pada pengobatan disebut juga dengan herbal medicine (Dubick, 1986). Salah satu tanaman yang termasuk tanaman herbal medicine adalah Sirih Merah (Piper crocatum Ruiz \& Pav.). Beberapa penelitian sebelumnya menunjukkan bahwa komponen yang terkandung dalam minyak atsiri mempunyai aktivitas antibakteri yaitu dapat menghambat atau membunuh pertumbuhan bakteri (Yuksel dkk., 2006).

Minyak atsiri memiliki sifat mudah menguap dan mudah terdekomposisi oleh panas, kelembaban udara, cahaya, maupun oksigen (Bilia dkk., 2014). Meskipun diketahui memiliki aktivitas antibakteri, sifat minyak atsiri tersebut dapat menjadi masalah apabila digunakan langsung. Oleh karena itu, diperlukan pengembangan teknologi formulasi yang mampu melindungi minyak atsiri dari degradasi sehingga dapat mengoptimalkan aktivitas dan efektivitasnya.

$\begin{array}{cc}\text { Minyak atsiri ini } \begin{array}{r}\text { dapat } \\ \text { dipresentasikan }\end{array} \text { menjadi } & \text { sediaan }\end{array}$ konvensional berupa sediaan emulsi. Emulsi merupakan sediaan heterogen yang terdiri atas dua cairan dalam sistem dispersi dimana fase cairan satu terdispersi dengan sangat halus ke dalam fase cairan lainnya (Anonim, 1979). Dengan perkembangan teknologi formulasi minyak atsiri bisa dibentuk juga menjadi sediaan dispersi yang lain yaitu mikroemulsi. Mikroemulsi adalah dispersi sebagaimana emulsi namun partikel mempunyai ukuran mikro. Akibat dari ukuran partikel yang sangat berbeda akan bisa mempengaruhi availabilitas dan aktivitas antibakteri, makin kecil ukuran partikel fase dispers makin baik bioavailabilitasnya.

\section{METODOLOGI \\ Bahan}

Daun Sirih Merah, tween-80, span-80, PEG-400, Escherichia coli ATCC 25922, media Mueller Hinton Broth (MHB)

\section{Alat}

Alat gelas, neraca analitik (Santorius BP 310), magnetic stirrer (Labtech ST 12), Particle Size Analyzer (Horiba Scientific SZ100), hotplate (Cimarec 2 Thermolyne), autoklaf (Sakura, OSK 6508 Steam Pressure Apparatus), shaker incubator (OSK Controller Incubator), inkubator (Imperial III Incubator), vortex mixer (Thermo Scientific), pemanas listrik, almari pendingin, spektrofotometer (UV-1700 PharmaSpec Shimadzu), LAF cabinet (ESCO Class II Biosafety Cabinet), bunsen, ose, Eppendorf steril, mikropipet, yellow tip, blue tip, vial, tabung reaksi, wadah plastik, rak rabung reaksi, seperangkat alat destilasi.

\section{Jalannya Penelitian}

Determinasi Tanaman

Dilakukan oleh Laboratorium Sistematika Tumbuhan Fakultas Biologi Universitas Gadjah Mada Yogyakarta, menyatakan kebenaran tanaman sirih merah (Piper crocatum Ruiz. \& Pav) yang masuk dalam suku Piperaceae.

Destilasi Minyak Sirih Merah (MSM)

Daun sirih didestilasi selama 4 jam dengan uap dan air, minyak hasil destilasi ditampung dalam corong pisah, dipisahkan. MSM dibebaskan dari air dengan natrium sulfat anhidrat, didapat rendemen $0,11 \%$ $\mathrm{v} / \mathrm{b}$.

Pembuatan Emulsi

Optimasi formula MSM dalam bentuk emulsi pada berbagai variasi HLB (Tabel I).

Dimasukkan ke dalam vial paraffin cair, MSM, tween-80 dan span-80 kemudian diaduk dengan magnetic stirrer selama 
Tabel I. Formula MSM bentuk emulsi

\begin{tabular}{ccccccc}
\hline No. & MSM (g) & Parafin cair (g) & Tween 80 (g) & Span 80 (g) & Air (g) & HLB \\
\hline 1 & 0,125 & 0,875 & 0,500 & - & 3,500 & 15 \\
2 & 0,125 & 0,875 & 0,125 & 0,375 & 3,500 & 7 \\
3 & 0,125 & 0,875 & - & 0,500 & 3,500 & 4,3 \\
4 & 0,125 & 0,875 & 0,375 & 0,125 & 3,500 & 12,3 \\
5 & 0,125 & 0,875 & 0,250 & 0,250 & 3,500 & 9,65 \\
6 & 0,125 & 0,875 & - & 0,500 & 3,500 & 4,3 \\
\hline
\end{tabular}

Tabel II. Formula MSM dalam bentuk mikroemulsi

\begin{tabular}{cccccc}
\hline No. & MSM (g) & Parafin cair (g) & Tween 80 (g) & PEG 400 (g) & Air (g) \\
\hline 1 & 0,125 & 0,125 & 1,250 & - & 3,500 \\
2 & 0,125 & 0,125 & 0,625 & 0,625 & 3,500 \\
3 & 0,125 & 0,125 & 0,417 & 0,833 & 3,500 \\
4 & 0,125 & 0,125 & 0,313 & 0,937 & 3,500 \\
5 & 0,125 & 0,125 & 0,25 & 1 & 3,500 \\
6 & 0,125 & 0,125 & 0,208 & 1,042 & 3,500 \\
7 & 0,125 & 0,125 & 0,179 & 1,071 & 3,500 \\
8 & 0,125 & 0,125 & 0,156 & 1,094 & 3,500 \\
9 & 0,125 & 0,125 & 0,139 & 1,111 & 3,500 \\
10 & 0,125 & 0,125 & 0,125 & 1,125 & 3,500 \\
11 & 0,125 & 0,125 & - & 1,250 & 3,500 \\
12 & 0,125 & 0,125 & 0,625 & 0,625 & 3,500 \\
13 & 0,125 & 0,125 & 0,833 & 0,417 & 3,500 \\
14 & 0,125 & 0,125 & 0,937 & 0,313 & 3,500 \\
15 & 0,125 & 0,125 & 1,000 & 0,250 & 3,500 \\
16 & 0,125 & 0,125 & 1,014 & 0,236 & 3,500 \\
17 & 0,125 & 0,125 & 1.071 & 0,179 & 3,500 \\
18 & 0,125 & 0,125 & 1.094 & 0,156 & 3,500 \\
19 & 0,125 & 0,125 & 1.111 & 0,139 & 3,500 \\
20 & 0,125 & 0,125 & 1.125 & 0,125 & 3,500 \\
\hline
\end{tabular}

5 menit. Emulsi yang didapatkan disimpan dalam suhu kamar dan dijaga konstan (Mollet dan Grubermann, 2001). Emulsi yang paling stabil dipilih sebagai formula bentuk emulsi untuk percobaan aktivitas mikrobiologiknya.

Pembuatan Mikroemulsi

Optimasi formula MSM dalam bentuk mikroemulsi pada berbagai variasi rasio surfaktan-kosurfaktan (Tabel II). Dimasukkan ke dalam vial MSM, paraffin cair, tween-80, PEG-400, dan air kemudian diaduk dengan magnetic stirrer selama 5 menit. Emulsi yang berupa jernih (paling jernih) yang didapatkan disimpan dalam suhu kamar dan dijaga konstan (Mollet dan Grubermann, 2001). Emulsi yang paling jernih dipilih sebagai formula bentuk mikroemulsi untuk percobaan aktivitas mikrobiologiknya.

Volume Sedimentasi (F)

Tiap formula emulsi yang sudah dibuat dimasukkan ke dalam tabung reaksi berskala dan diamati pemisahan fase yang terjadi sampai dengan 2 jam setelah pembuatan. Hasil pemisahan fase dinyatakan dengan harga $\mathrm{F}$ dengan rumus $\mathrm{F}=\mathrm{Hu} / \mathrm{Ho} \ldots$ (1). Keterangan: $\mathrm{F}=$ rasio 
pemisahan fase, $\mathrm{Ho}=$ tinggi emulsi mula-mula, $\mathrm{Hu}=$ tinggi emulsi pada waktu pengamatan.

\section{Uji Mikrobiologi}

Alat-alat dan media sebelum digunakan disterilisasi terlebih dahulu dengan cara yang sesuai. Stok mikroba hasil kultur dalam media MHB diukur nilai OD $_{600 n m}$ (Optical Density) terlebih dahulu dengan spektrofotometer UV-Vis. Selanjutnya dilakukan pengenceran dengan media agar nilai $\mathrm{OD}_{600 \mathrm{~nm}}$ mikroba yang akan diuji sebesar 0,3 (untuk E.coli setara dengan $1-2 \times 10^{8} \mathrm{CFU} / \mathrm{mL}$ ). Suspensi kemudian diencerkan lagi 120 kali untuk mendapatkan nilai akhir $10^{6} \mathrm{CFU} / \mathrm{mL}$ dikarenakan untuk uji mikrodilusi ini terdapat $50 \mu \mathrm{L}$ suspensi bakteri dan $50 \mu \mathrm{L}$ sampel, sehingga setara dengan $5 \times 10^{5}$ $\mathrm{CFU} / \mathrm{mL}$ atau $5 \times 10^{4} \mathrm{CFU} / 100 \mu \mathrm{L}$.

Uji aktivitas antibakteri dilakukan terhadap bakteri Escherichia coli ATCC 25922 secara in vitro dengan metode mikrodilusi cair (broth microdillution method). Uji ini dilakukan untuk mengetahui persentase pengambatan sampel terhadap bakteri uji. Minyak atsiri sirih merah dibuat kadar 2,5\% b/b dengan dilarutkan menggunakan DMSO 5\%. Karena sampel uji dalam tiap well sebesar $50 \mu \mathrm{L}$ sedangkan volume total tiap well sebesar $100 \mu \mathrm{L}$ maka kadar minyak atsiri sirih merah dalam tiap well menjadi $1,25 \% \mathrm{~b} / \mathrm{b}$. Sampel yang diujikan antara lain sediaan MSM dalam bentuk emulsi, minyak atsiri daun sirih merah kadar 2,5\% b/b, blanko emulsi, MSM bentuk mikroemulsi kadar 2,5\%, blanko mikroemulsi, akuades dan DMSO sebagai kontrol pelarut, amoksisilin kadar 2,5\%b/b sebagai kontrol positif, dan kontrol media.

Pengujian dilakukan terhadap 1 plate uji dan 1 plate blanko. Plate uji berisi $50 \mu \mathrm{L}$ sampel dan $50 \mu \mathrm{L}$ suspensi bakteri. Sedangkan plate blanko berisi $50 \mu \mathrm{L}$ sampel dan $50 \mu \mathrm{L}$ larutan salin tanpa ditambahkan suspensi bakteri. Microplate diletakkan dalam kotak yang dilapisi tisu yang dibasahi selanjutnya diinkubasi pada suhu $37^{\circ} \mathrm{C}$ selama 18-24 jam menggunakan shaker incubator. Microplate dikeluarkan dari shaker incubator kemudian ditambahkan pada masing-masing well $10 \mu \mathrm{L}$, konsentrasi $5 \mathrm{mg} / \mathrm{mL}$ dan diinkubasi selama 4 jam pada temperatur $37^{\circ} \mathrm{C}$. Setelah inkubasi, microplate ditambahkan DMSO 1\% dan diinkubasi kembali selama 30 menit pada temperatur $37^{\circ} \mathrm{C}$ kemudian diukur nilai OD dengan ELISA reader pada panjang gelombang $570 \mathrm{~nm}$.

$\%$ Penghambatan $=$

$\left(1-\frac{\text { OD sempel uji }- \text { OD blanko sampel }}{\text { OD pelarut uji }- \text { OD blanko pelarut }}\right) \times 100 \%$ (2) (Quave dkk, 2008)

\section{HASIL DAN PEMBAHASAN Formulasi Sediaan Emulsi}

Hasil dari pembuatan emulsi yang paling stabil (harga $\mathrm{F}$ paling tinggi) adalah yang mempunyai nilai HLB 7, yang terdiri atas MSM $0,125 \mathrm{~g}$, paraffin cair $0,875 \mathrm{~g}$, tween-80 0,125g, span-80 0,375g dan air $3,500 \mathrm{~g}$. Hasil ini ditunjukan dengan harga $\mathrm{F}$ $=1$ selama pengamatan 2 jam. Kepada formula ini kemudian ditetapkan ukuran partikelnya dengan PSA dan diperoleh ratarata ukuran partikel yaitu $684,6 \mathrm{~nm}$ (Gambar 1).

\section{Formulasi Sediaan Mikroemulsi}

Hasil dari formulasi sediaan mikroemulsi diperoleh bentuk mikroemulsi/emulsi spontan dengan kriteria sediaan yang secara fisik transparan/jernih. Hasil itu didapat pada formula yang terdiri atas $0,125 \mathrm{~g}$ MSM, $0,125 \mathrm{~g}$ paraffin cair, $0,417 \mathrm{~g}$ tween-80, 0,833g PEG-400, dan 3,500g air. Sediaan mikroemulsi mempunyai ukuran partikel rata-rata 410,0 $\mathrm{nm}$ yang ditetapkan dengan PSA (Gambar 2). Ukuran partikel dari mikroemulsi bisa lebih kecil dikarenakan adanya kosurfaktan PEG-400. Kosurfaktan akan menyebabkan tegangan lateral $(\pi)$ menjadi tinggi. Dari rumus $\gamma_{i}=\gamma_{o} / w-\pi$ kalau tegangan lateral tinggi bisa berakibat $\gamma_{i}$ 


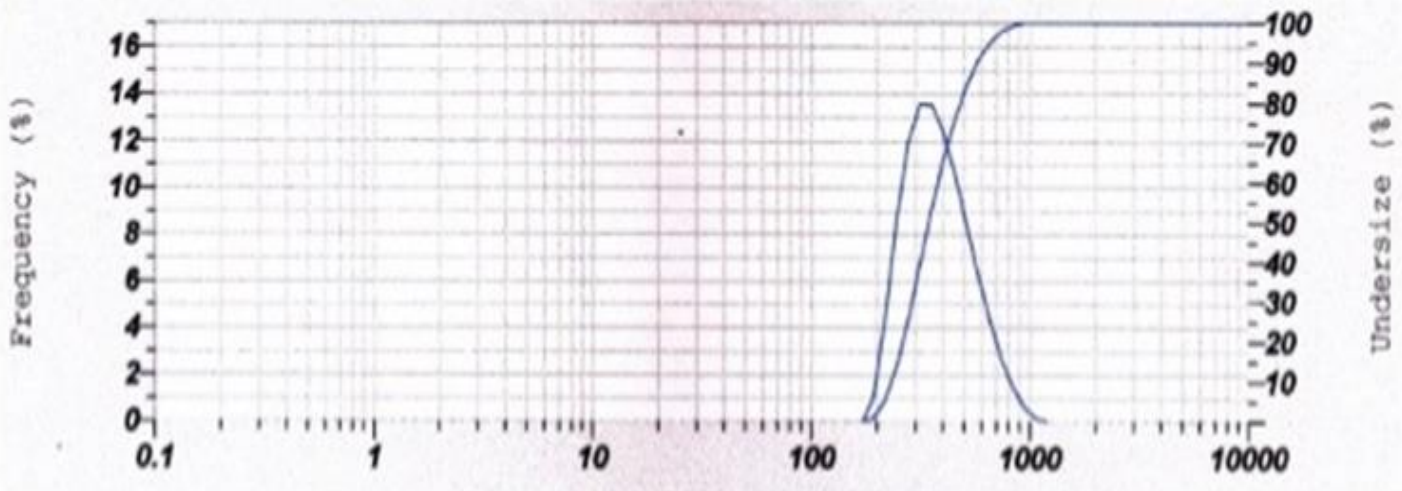

Gambar 1. Ukuran partikel fase dispers emulsi ditetapkan dengan PSA

\section{Calculation Results}

\begin{tabular}{ccccc}
\hline Peak No. & S.P.Area Ratio & Mean & S. D. & Mode \\
\hline 1 & 1.00 & $377.7 \mathrm{~nm}$ & $137.9 \mathrm{~nm}$ & $298.6 \mathrm{~nm}$ \\
2 & $\ldots$. & $\ldots . \mathrm{nm}$ & $\ldots . \mathrm{nm}$ & $\ldots . \mathrm{nm}$ \\
3 & $\ldots$. & $\ldots . \mathrm{nm}$ & $\ldots . \mathrm{nm}$ & $\ldots . \mathrm{nm}$ \\
Total & 1.00 & $377.7 \mathrm{~nm}$ & $137.9 \mathrm{~nm}$ & $298.6 \mathrm{~nm}$ \\
\hline
\end{tabular}

\section{Cumulant Operations}

Z-Average : $684.6 \mathrm{~nm}$; PI : 0.534

menjadi negative sehingga terjadilah pemecahan partikel menjadi jauh lebih kecil dan secara spontan, dan terlihat transparan (Denoel, dkk, 1981)

\section{Uji Antibakteri}

Hasil uji penghambatan pertumbuhan bakteri Escherichia coli ATCC 25922 (Gambar 3) diperoleh bahwa penghambatan pertumbuhan E. coli MSM dalam bentuk mikroemulsi $(49,58 \%)$ lebih besar dari MSM dalam bentuk emulsi $(17,45 \%)$. Di dalam bentuk emulsi MSM terdispersi sebagai fase internal dengan ukuran partikel rata-rata adalah $684,6 \mathrm{~nm}$ sedangkan MSM dalam bentuk mikroemulsi terdispersi sebagai fase dispers dengan ukuran partikel $410,0 \mathrm{~nm}$. Partikel yang lebih kecil akan menyebabkan luas antarmuka menjadi lebih besar, dan akibatnya bioavailabilitas obat akan lebih baik (Kammona dan Kiparissides, 2012).

Analisis Perbandingan Aktivitas Antibakteri MSM dalam bentuk sediaan emulsi dan mikroemulsi kemudian dilakukan. MSM dalam DMSO memiliki efektivitas yang paling tinggi untuk menghambat pertumbuhan bakteri dikarenakan droplet MSM nya langsung berefek pada bakteri dan terpenetrasi kedalam membran dengan lebih efektif. Namun dalam penggunaan MSM secara langsung dapat memberikan rasa yang tidak nyaman karena baunya yang menyengat, berminyak, dan dapat menyebabkan iritasi pada konsentrasi tertentu. Oleh karena itu dibuatlah formulasi MSM agar lebih nyaman dalam penggunaannya.

Untuk mengetahui perbedaan dari tiap kelompok data dilakukan analisis statistik. Uji normalitas yang digunakan adalah Saphiro-Wilk. Uji ini dilakukan pada setiap kelompok hari dan didapatkan hasil bahwa data terdistribusi normal. Selanjutnya dilakukan uji homogenitas varian dengan metode uji Levene. Berdasarkan hasil analisis, p-value >0,05. 


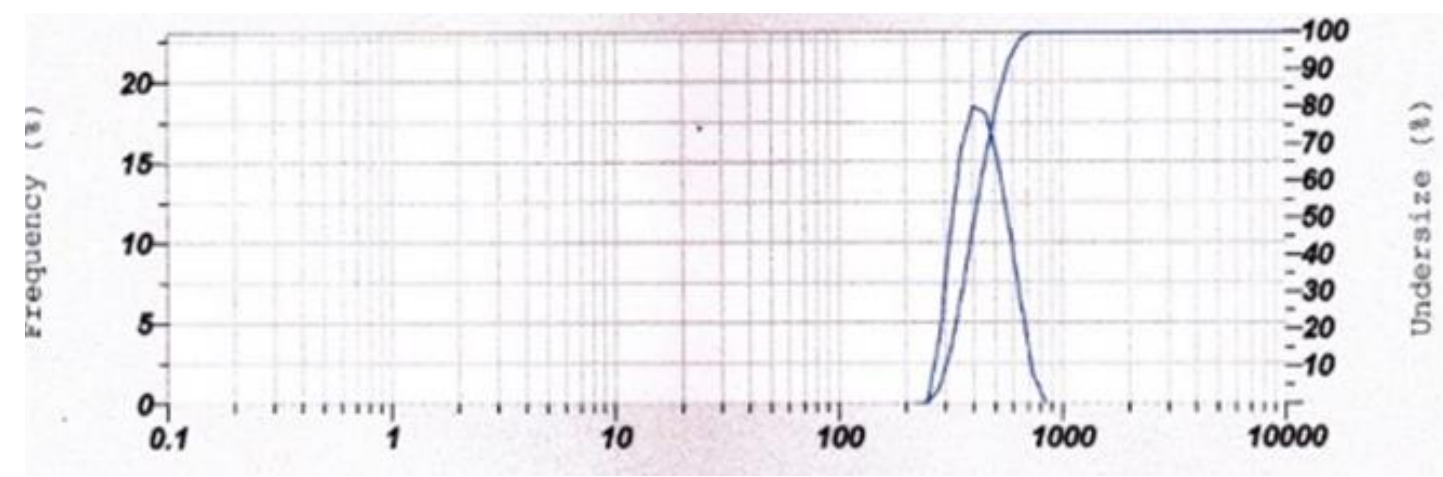

Gambar 2. Ukuran partikel fase dispers mikroemulsi ditetapkan dengan PSA

\section{Calculation Results}

\begin{tabular}{ccccc}
\hline Peak No. & S.P.Area Ratio & Mean & S. D. & Mode \\
\hline 1 & 1.00 & $421.0 \mathrm{~nm}$ & $99.6 \mathrm{~nm}$ & $381.3 \mathrm{~nm}$ \\
2 & $\ldots$. & $\ldots . \mathrm{nm}$ & $\ldots . \mathrm{nm}$ & $\ldots . \mathrm{nm}$ \\
3 & $\ldots$. & $\ldots . \mathrm{nm}$ & $\ldots . \mathrm{nm}$ & $\ldots . \mathrm{nm}$ \\
Total & 1.00 & $421.0 \mathrm{~nm}$ & $99.6 \mathrm{~nm}$ & $381.3 \mathrm{~nm}$ \\
\hline
\end{tabular}

\section{Cumulant Operations}

Z-Average : $410.0 \mathrm{~nm}$; PI : 0.304

Hal ini berarti ragam antar kelompok perlakuan homogen. Apabila dilakukan uji perbandingan berganda, maka analisis yang digunakan Tukey HSD. Data yang terdistribusi normal selanjutnya dianalisis menggunakan ANOVA, dari hasil uji dapat disimpulkan bahwa terdapat perbedaan persentase penghambatan antar perlakuan. Oleh karena itu dilanjutkan dengan uji perbandingan berganda, yakni dengan uji Tukey HSD untuk mengetahui antar perlakuan yang mana yang menghasilkan persentase penghambatan yang berbeda. Hasil analisis Tukey HSD menunjukkan bahwa bentuk mikroemulsi MSM, emulsi MSM dan MSM tanpa diformulasi memiliki aktivitas antibakteri yang berbeda signifikan $(\mathrm{p}<0,05)$.

Aktivitas mikroemulsi blank lebih rendah dibandingkan mikroemulsi. Hasil analisis menggunakan uji Tukey HSD menunjukkan bahwa aktivitas mikroemulsi blank dan mikroemulsi MSM berbeda

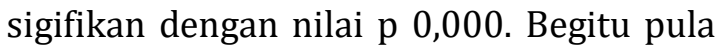
dengan nilai persen penghambatan emulsi blank yang lebih rendah jika dibandingkan dengan emulsi yang mengandung MSM. Hasil analisis menunjukkan aktivitas emulsi dan emulsi blank berbeda signifikan dengan nilai signifikansi 0,000 .

Komponen dalam emulsi dan mikroemulsi selain berfungsi untuk membentuk dan menstabilkan sediaan diduga dapat mendukung aktivitas antimikroba. Ukuran droplet mikroemulsi yang kurang dari $500 \mathrm{~nm}$ bermanfaat untuk membantu zat aktif dalam melakukan mekanisme kerja saat penetrasi kedalam sel mikroba. MSM yang diformulasi menjadi mikroemulsi memiliki aktivitas antibakteri yang tidak berbeda signifikan dengan kontrol positif yang digunakan yaitu Amoxicillin dengan nilai signifikansi 0,002. Persen hambatan Amoxicillin terhadap bakteri Escherichia coli adalah 74,34\%. Sehingga formulasi MSM mikroemulsi dapat memberikan efek yang cukup tinggi dibandingkan dengan antibiotik yang sudah ada sebelumnya. Dengan melakukan formulasi MSM bentuk sediaan memiliki 


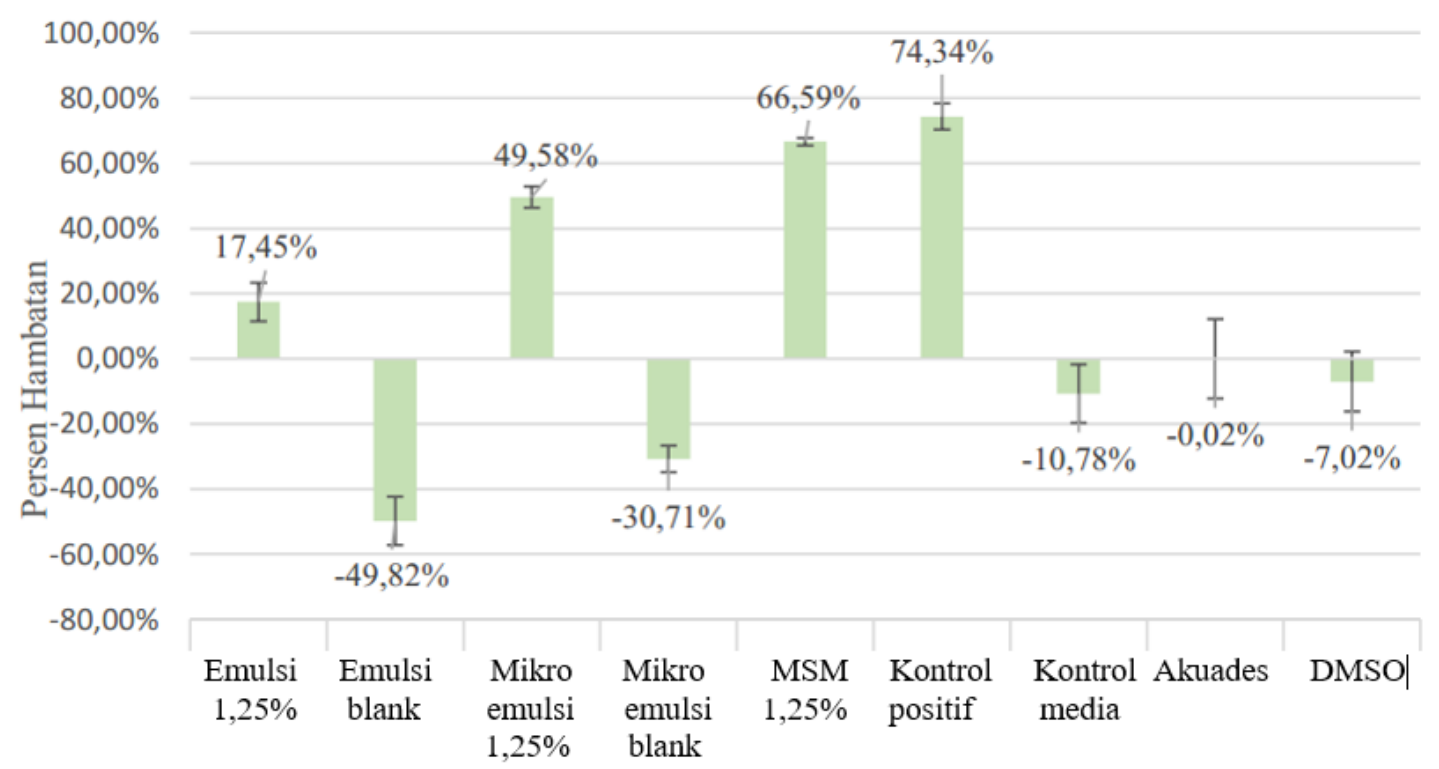

Gambar 3. Perbandingan aktivitas emulsi, minyak atsiri, dan mikroemulsi

beberapa manfaat antara lain menjaga stabilitas bahan berkhasiat yang dikandung, lebih praktis, aman dan menyenangkan dalam pemakaian.

Akuades dan DMSO yang digunakan diuji efek antibakterinya, bertujuan untuk membandingkan aktivitas penghambatannya dengan MSM agar dapat diketahui apakah pelarut yang digunakan mempengaruhi aktivitas antibakteri dari sampel secara signifikan atau tidak. Akuades memiliki daya hambat $-0,02 \%$ sedangkan DMSO memiliki daya hambat sebesar $-7,02 \%$ yang berarti keduanya tidak menghambat pertumbuhan bakteri.

Persentase penghambatan yang negatif dapat terjadi dikarenakan absorbansi sampel yang lebih tinggi daripada blanko. Hal ini menggambarkan bahwa selama masa inkubasi terjadi pertumbuhan bakteri pada well yang berisi sampel. Sampel yang digunakan pada konsentrasi rendah tidak dapat menghambat pertumbuhan bakteri dengan dilakukannya inkubasi namun pada konsentrasi lebih tinggi, senyawa mampu menghambat pertumbuhan sehingga didapat nilai persen penghambatan yang positif. Formulasi MSM mikroemulsi dapat meningkatkan efektivitasnya dalam menghambat mikroba. Mikroemulsi merupakan partikel yang memiliki ukuran mikrometer. Dengan ukurannya yang kecil maka partikel mikro dapat menembus sel bakteri yang mempunyai ukuran diameter hingga skala mikrometer sehingga dapat menghambat pertumbuhan bakteri dengan lebih efektif (Brooks dkk., 2007). Ukuran partikel yang kecil membuat mikroemulsi memiliki kestabilan yang lebih baik dibandingkan emulsi.

\section{KESIMPULAN}

Emulsi MSM dapat diformulasi dengan komposisi terbaik MSM 0,125g, parafin cair 0,875 gram, tween-80 0,125g, span-80 0,375g, akuades 3,500g, mempunyai diameter rata-rata partikel 684,6 nm. Mikroemulsi MSM dapat diformulasi dengan komposisi terbaik MSM $0,125 \mathrm{~g}$, parafin cair $0,125 \mathrm{~g}$, tween-80 0,417g, PEG-400 0,833g, akuades 3,500g mempunai diameter rata-rata partikel 410 nm. Mikroemulsi MSM memiliki penghambatan pertumbuhan sebesar 49,58 $\pm 3,27 \%$ terhadap bakteri Escherichia coli ATCC 25922 lebih baik dibandingkan dengan emulsi MSM dengan penghambatan 
$17,45 \pm 5,92 \%$. MSM dalam DMSO 5\% memiliki aktivitas penghambatan yang lebih besar daripada bentuk yang telah diformulasi yaitu 66,59 $\pm 1,18 \%$.

\section{UCAPAN TERIMA KASIH}

Penulis mengucapkan terimakasih kepada Fakultas Kedokteran UGM yang telah memberikan bantuan dana melalui Hibah Dana Masyarakat, Fakultas Kedokteran UGM Tahun 2012.

\section{DAFTAR PUSTAKA}

Anonim, 1979, Farmakope Indonesia, Edisi III, Departemen Kesehatan Republik Indonesia, Jakarta.

Bilia, A. R., Guccione, C., Isacchi, B., Righeschi, C., Firenzuoli, F., dan Bergonzi, M.C., 2014, Essential Oils Loaded in Nanosystem: A Developing Strategy for a Successful Therapeutic Approach, Evidence Based Complementary and Alternative Medicine, 1-14.

Brooks, G. F., Carroll, K.C., Butel, J.S., \& Morse, S.A., 2007, Jawetz, Melnick \&
Adelsberg's Medical Microbiology, 24th Edition, The McGraw-Hill's Company, New York.

Denoel, A, Jaminet, Fr., and Moes, A., 1981, Pharmacy Galenique tome II, Les Press Univ Liege, Liege.

Dubick, M. A, 1986, Historical perspectives on the use of herbal preparations to promote health. JN The Journal of Nutrition, University of California, Davis, School of Medicine, 1348-1349.

Kammona, O., Kiparissides, C., 2012, Recent Advances in Nanocarrier-based Mucosal Delivery of Biomolecules, Journal of Controlled Release, 161, 781-794.

Mollet, H., dan Grubermann, A., 2001, Formulation Technology: Emulsions, Suspensions, Solid Form, 261-262, Wiley-Vch, Toronto, 73.

Yuksel, K., Ucan, U.C., Kartal, M., Altun, M.L., Aslan, S., Sayar, E., and Ceyhan, T., 2006, GC-MS Analysis and Antibacterial Activity of Cultivated Satureja cuneifolia Ten Essential Oil, Turkey Journal Chemistry, 30, 253259. 